\title{
DIAGNOSIS KESULITAN BELAJAR IPA (SAINS) PESERTA DIDIK SMP NEGERI 3 SUMENEP
}

\author{
Ngadi \\ SMP Negeri 3 Sumenep
}

\begin{abstract}
ABSTRAK
Peserta didik berkesulitan belajar dapat mengganggu efektifitas pembelajaran. Ragam kesulitan belajar harus dilokalisasi guru secara tepat dan akurat, sehingga guru memiliki pijakan kuat dalam memberikan perlakuan pembelajaran (classroom action) kepada peserta didik yang efektif dan efisien, baik melalui pengajaran klasikal ataupun remidial. Melalui metode analisis kluster nonhierarki atau K-Means Cluster dengan bantuan software SPSS 16.0 serta menggunakan analisis crosstabing antara hasil tes diagnostik dan nilai UTS terpetakan jenis kesulitan belajar IPA (Sains) peserta didik sehingga guru dapat meramalkan penyebab dan tidakan alternatif yang tepat mengatasi kesulitan belajar IPA (Sains) peserta didiknya.
\end{abstract}

\section{Kata kunci : Peserta didik, Efektifitas belajar, Analisis kluster nonhierarki.}

\section{PENDAHULUAN}

Sebagai garda terdepan dalam membangun bangsa, guru harus memberikan pelayanan maksimal terhadap kegiatan pembelajarannya kepada semua peserta didiksecara demokratis, berkeadilan, tidak diskriminatif yang menjunjung hak asasi manusia, nilai keagamaan, budaya, kemajemukan, bahkan kelainan fisik, emosional, mental, intelektual, dan/atau sosial (UU RI No. 20 tahun 2003 tentang Sisdiknas).Sebagai individu, setiap peserta didik memiliki karakteristik berbeda antara yang satu dengan yang lain. Sering guru mendapatkan peserta didikmemiliki kecerdasan intelektual baik yang sering dikategorikan sebagaigifted learners(Santrock, 2010), tetapi sering juga menemukan peserta didik tidak dapat belajar sebagaimana mestinya, berkemampuan kurang atau berkesulitan belajar yang disebut difficulty learners. Guru umumnya mengabaikan jenis peserta didik difficulty learners, karena mereka dianggap mengganggu kegiatan belajar serta pencapaian target pengajaran.Pada dasarnya, peserta didikberkesulitan belajar bersumber dari dua faktor (Hidayati, 2010), yaitu:(1) faktor internal,yaitu hal-hal atau keadaankeadaan yang muncul dari dalam diri peserta didik yang disebabkan faktor psikologi, fisiologi, dan intelegensi peserta didik; dan (2) faktor eksternal, yaitu keadaan atau hal-hal yang datang dari luar diri peserta didik yang disebabkan oleh faktor-faktor sosial (hubungan antarkeluarga, masyarakat, guru, lainnya), lingkungan belajar, penguasaan materi pelajaran (SK/KD), serta cara belajar peserta didik (Syah,2010).

Munculnyapeserta didik berkesulitan belajar akanditandai denganmotivasi belajar dan kinerja (prestasi) akademik peserta didik yang menurun,serta berperilakuyang tidak relevan dengan yang diharapkan (Hakim, 2000). Diperlukan langkah-langkah tertentu yang mendalam dan terstruktur agar dapat memetakanletak (melokalisasi) kesulitan belajar peserta didik, mengidentifikasi kelemahan dan kekuatan peserta didik (Hudgins, 1985), sehingga guru memiliki acuan dalammemberikan terapi pembelajaran (action classroom)secara efektif dan dan efisien.

Tes diagnostik adalah tes spesifik yang dirancanguntuk menentukan 
kebutuhan pembelajaran spesifik peserta didik (Santrock, 2010).Terdapat bebeberapa pendekatan yang dapat digunakan dalam tes diagnostik, yaitu: (1) pendekatan profil materi, (2) pendekatan pengetahuan prasyarat, (3) pendekatan pencapaian indikator, (4) pendekatan kesalahan konsep atau misconception, dan (5) pendekatan pengetahuan terstruktur untuk memecahkan masalah (Depdiknas, 2003).Melalui tes diagnostik, guru dapat: (1) mengidentifikasi hasil belajar yang belum dicapai peserta didik, dan (2) mengidentifikasi permasalahan utama yang menyebabkan peserta didik belum mencapai hasil belajar (Depdiknas, 2003). Hasil tes diagnostik adalah menjadi dasar acuan (referensi) guru untuk memberikan tindakan pembelajaran lanjutan, baik melalui pengajaran reguler atau remidial.

SMP Negeri 3 Sumenep adalah salah satu sekolah menengah di tengah kota yang memiliki 599peserta didik (Data Sekolah Tahun 2012/2013). Budaya pemilih sekolah (orang tua pendaftar calon siswa) yang umumnya menempatkan SMP Negeri 3 Sumenep sebagai "pilihan ke-tiga" (setelah jika tidak diterima di SMP Negeri 1 dan SMP Negeri 2 Sumenep) menyebabkansetiap tahun jumlah pendaftar lebih kecil daripada kuota jumlah pagu yang disediakan.Artinya, SMP Negeri 3 Sumenep "tidak dapat memilih"calon siswa berdasarkan kriteria (kelayakan) kompetensiminimal akademik atau nonakademik.Meskipun dalam teori perkembangan Jean Piaget(seperti karakteristik sekolah normal), mereka dapat diklasifikasikanberada pada tahap kemampuan berpikir fase operasional formal (Hudgins; 1987; Santrock, 2010),faktanya mereka lemah dalam menganalisis suatu kejadian,lemah berpikir simbolis, dan lemah dalam berpikir abstrak (nonvisual).
Dalam konteks matapelajaran IPA, sebagian besar peserta didik SMPN 3 Sumenep menganggap ia adalah matapelajaran yang sulit, meskipun ratarata mereka menyenanginya. Matapelajaran IPA yang berkaitan dengan cara mencari tahu tentang alam melalui proses penemuan secara sistematis dan ilmiah (saintifik) seperti yang dilakukan para ilmuwan (Santrock, 2010)faktanya sering disajikan oleh guru sekedar penguasaan kumpulan pengetahuan berupa fakta-fakta, konsep-konsep atau prinsip-prinsip. Akibatnya, banyak peserta didik yang berkemampuan rendah bernalar menggunakan IPA. Sebagai "ilmuwan remaja," maka pembelajaran IPA harusnya lebih mendorong peserta didik untuk mampu dalam: (1) memahami konsep;(2) mengumpulkan dan menglasifikasi data; (3) mengintepretasi data dan membuat grafik; (4) memanipulasi dan menganalisis data; (5) memahami hubungan spasial; (6) mengukur dan mengamati; (7) melakukan eksperimen; (8) memprediksi jawaban dan hipotesis;(7) menyimpulkan data;serta (10) mengolah angka dan mengaplikasi untuk memecahkan masalah (Trianto, 2012; Santrock, 2010). Kesenjangan harapan dan fakta inilah yang menjadi pokok permasalahan mengapa matapelajaran IPA dianggap sulit oleh peserta didik.

Penelitian ini bertujuan memetakan (melokalisasi) jenis-jenis kesulitan belajar IPA peserta didik SMP Negeri 3 Sumenep. Output yang diharapkan adalah tersedianya peta (terlokalisasi) jenis-jenis kesulitan belajar IPA, sehingga diharapkan dapat menjadi acuan dan pertimbangan bagi para guru IPA untuk mengambil keputusan untuk memberikan tindakan (action classroom) yang tepat daam rangka memperbaiki kinerja pembelajarannya, baik dalam bentuk reguler maupun remidial. 


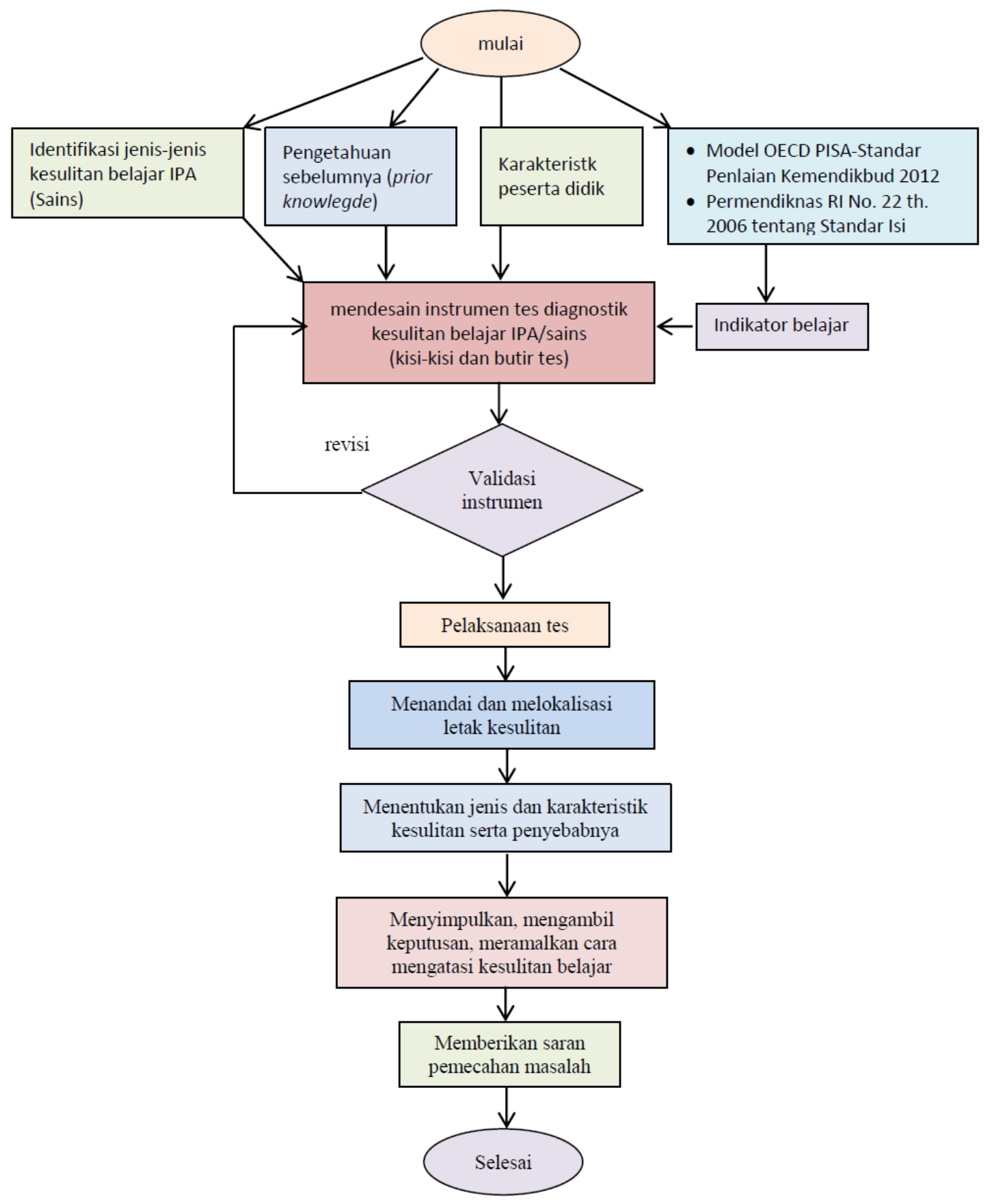

Gambar 1. Diagram alir prosedur tes diagnostik

\section{METODE}

Jenis penelitian ini adalah analisis kuantitatif-deskriptif, bertujuan melokalisasi dan mendeskripsikan jenisjeniskesulitan belajar IPA peserta didik SMP Negeri 3 Sumenep.Pelaksanaan penelitian dilakukan pada akhir Semester Genap Tahun Pelajaran 2013/2014pada Oktober 2013, dimana subyek penelitian adalah Kelas VIII-1 dan VIII-4dengan jumlah total 46 peserta didik, yang terdiri dari 29peserta didik berjenis kelamin perempuan dan 17 peserta didik berjenis laki-laki.

Pengambilan data dilakukan dengan cara tes terdiri dari 14 butir bertipe uraian (subyektif)di mana subyek memperoleh: skor 2 jika mampu menjawab benar disertai dengan alasan benar, skor 1 jika jawaban benar tetapi 
alasan salah atau sebaliknya, dan skor 0 jika tidak menjawab atau jawaban sama sekali salah. Materi tes adalah IPA terpadu (integrative science), bentuk tes mengadopsi model tes PISA (Programme for International Student Assessment) yang dikembangkan oleh OECD (Organization for Economic Operation and Development)tahun 2012, yang mengukur kompetensi saintifik siswa (Tabel 1) dalam: (1) memahami konsep;
(2) mengumpulkan dan menglasifikasi data; (3) mengintepretasi data dan membuat grafik; (4) memanipulasi dan menganalisis data; (5) memahami hubungan spasial; (6) mengukur dan mengamati; (7) melakukan eksperimen; (8) memprediksi jawaban dan hipotesis; (7) menyimpulkan data; serta (10) mengolah angka dan mengaplikasi untuk memecahkan masalah (Trianto, 2012; Santrock, 2010).

Tabel 1. Kisi-kisi (desain) tes diagnostik profil peserta didik dalam penguasaan materi

\begin{tabular}{clc}
\hline Kode & Jenis Kompetensi & Jumlah butir \\
\hline 01 & Memahami_konsep & 3 \\
02 & Mengumpulkan dan menglasifikasi data & 2 \\
03 & Mengintepretasi data dan membuat grafik & 1 \\
04 & Memanipulasi dan menganalisis data & 1 \\
05 & Memahami hubungan spasial & 1 \\
06 & Mengukur dan mengamati & 1 \\
07 & Melakukan eksperimen & 1 \\
08 & Memprediksi jawaban dan hipotesis & 2 \\
09 & Menyimpulkan data & 1 \\
10 & Mengolah angka dan memecahkan masalah & 1 \\
\hline Jumlah item & 14
\end{tabular}

Sumber: peneliti

Penggunaan model tes di atas diharapkan agar dapat lebih spesifik mendiagnosis jenis-jenis kesulitan belajar IPA siswa melalui pendekatan pengetahuan terstruktur untuk memecahkan masalah (saintifik) serta arah pengembangan pembelajaran matapelajaran IPA ke depan menuju Kurikulum 2013 (Dokumen Kurikulum 2013 Kemendikbud, Desember 2012).

Analisis data menggunakan analisis kluster nonhierarki atau $K$-Means Clusterdengan dua kluster (kelompok), yaitu kelompok atas dan kelompok bawah,menggunakan bantuan
softwareSPSS 16.0.Tujuan analisis ini adalah mengelompokkan obyek berdasarkan kesamaan karakteristik peserta didikberdasarkan hasil uji tes diagnostik.Penggunaan teknik inidiharapkan lebih menjamin hasil pengelompokkan yang memiliki homogenitas tinggi antarsubyek dalam satu kelmpok dan mempunyai heterogenitas antarkelompok.Selanjutnya, masing-masing kelompok hasil analisis kluster dilakukan proses profiling untuk menjelaskan karakteristik masing-masing kelompok berdasarkan jenis kesulitan belajar

IPA. 


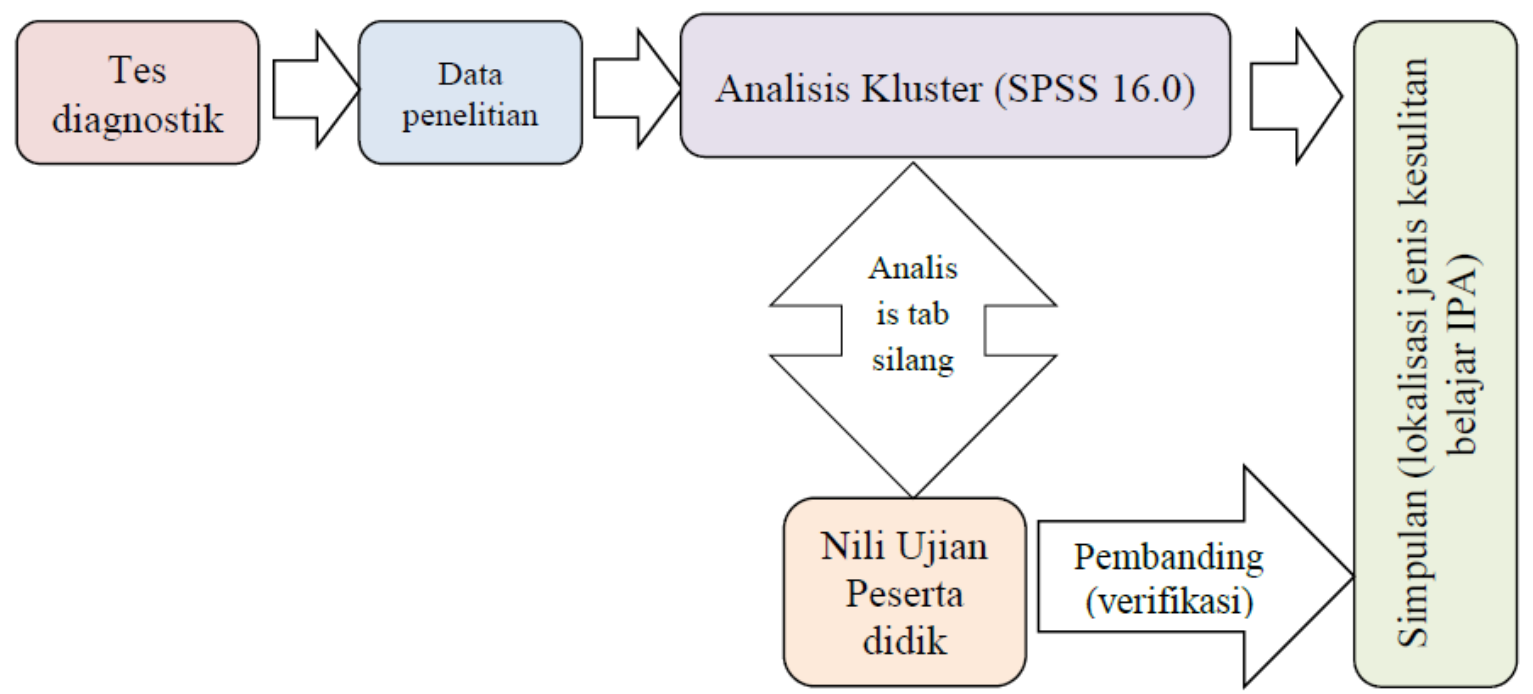

Gambar 2. Skema analisis data

Sebagai pembanding, dilakukan analisis crosstabing antara hasil analisis kluster terhadap data klarifikator ketuntansan belajar Ujian Tengah Semester (UTS), yang bertujuan untuk mengklarifikasi kesuaian antara subyek kelompok bawah dari peserta didik yang tidak tuntas UTS terhadap subyek kelompok atas dari peserta didik yang tuntas UTS. Cara ini diharapkan dapat menguji kesesuaian tes UTS yang dikembangkan guru terhadap tes diagnostik yang dikembangkan peneliti.Hasil analisis adalah akan terpetakan jenis kesulitan belajar IPA (Sains) untuk kelompok peserta didik berkategori kelompok bawah dan kelompok atas, sehingga dapat meramalkann penyebab dan tidakan alternatif yang tepat mengatasi kesulitan belajar IPA (Sains) peserta didik.

\section{HASIL DAN PEMBAHASAN \\ Lokalisasi Kesulitan Belajar IPA Peserta Didik}

Berdasarkan perhitungan analisis kluster menunjukkan, pada Kelas VIII-1 diperoleh 7 peserta didik berkarakter kategori kelompok atas dan 16 peserta didik kelompok bawah. Sedangkan pada kelas VIII-4 terdapat 9 peserta didik kelompok atas dan 14 peserta didik kelompok bawah (Tabel 2). Mengacu Tabel 3menunjukkan, subyek kelas VIII-1 tidak memiliki kemampuan IPA (Sains) dalam: (1) memahami hubungan spatial; (2) mengukur dan mengamati;
(3) mengumpulkan dan menglasifikasi data. Sementara, mereka berkemampuan (1) mengintepretasi data dan membuat grafik, akan tetapi dengan skor kecil yang hanya pada tingkatan menjawab benar tanpa disertai alasan. Sementara itu, subyek kelompok atas menunjukkan tidak mampu dalam: (1) memahami hubungan spatial; (2) mengukur dan mengamati. Namun, subyek kelompokatas unggul dalam: (1) mengolah angka dan memecahkan masalah, pada tingkatan menjawab benar dengan tidak disertai alasan.

Tabel 2. Jumlah Peserta Didik untuk Masing-masing Kelompok

\begin{tabular}{|c|c|c|c|c|c|c|c|c|}
\hline \multirow{2}{*}{} & \multicolumn{4}{|c|}{ Kelas VIII-1 } & \multicolumn{4}{c|}{ Kelas VIII-4 } \\
\cline { 2 - 8 } & Freq & Percent & $\begin{array}{c}\text { Valid } \\
\text { Percent }\end{array}$ & $\begin{array}{c}\text { Cum } \\
\text { Percent }\end{array}$ & Freq & Percent & $\begin{array}{c}\text { Valid } \\
\text { Percent }\end{array}$ & $\begin{array}{c}\text { Cum } \\
\text { Percent }\end{array}$ \\
\hline $\begin{array}{l}\text { Valid } \\
\text { kelompok } \\
\text { bawah }\end{array}$ & 16 & 69.6 & 69.6 & 69.6 & 14 & 60.9 & 60.9 & 60.9 \\
\hline
\end{tabular}




\begin{tabular}{|l|c|c|c|c|c|c|c|c|}
\hline $\begin{array}{l}\text { kelompok } \\
\text { atas }\end{array}$ & 7 & 30.4 & 30.4 & 100.0 & 9 & 39.1 & 39.1 & 100.0 \\
\hline Total & 23 & 100.0 & 100.0 & & 23 & 100.0 & 100.0 & \\
\hline
\end{tabular}

Sumber : Hasil olahan SPSS 16.0

Subyek kelas VIII-4, pada kelompok bawah menunjukkan bahwa mereka tidak mampu: (1) mengumpulkan dan menglasifikasi data, (2) memahami hubungan spasial, (3) mengukur dan mengamati, (4) memprediksi jawaban dan hipotesis. Sementara, mereka mampu dalam: (1) melakukan eksperimen, akan tetapi pada tingkatan (level) menjawab benar tanpa alasan. Subyek kelompok atas menunjukkan mereka tidak mampu dalam: (1) mengumpulkan dan menglasifikasi data; (2)memahami hubungan spasial; (3) mengukur dan mengamati; dan (4) menyimpulkan data. Namun, mereka sangat baik dalam: (1) memprediksi jawaban dan hipotesis, pada level menjawab benar dengan disertai alasan yang benar.

Tabel 3. Final Cluster Centers

\begin{tabular}{|l|l|c|c|c|c|}
\hline \multirow{2}{*}{ No } & \multirow{2}{*}{ Aspek kemampuan saintifik } & \multicolumn{2}{c|}{ Kelas VIII-1 } & \multicolumn{2}{c|}{ Kelas VIII-4 } \\
\cline { 3 - 6 } & & \multicolumn{2}{c|}{ Kelompok } & \multicolumn{2}{c|}{ Kelompok } \\
\cline { 3 - 6 } & & bawah & atas & bawah & atas \\
\hline 1. & Memahami konsep & .75 & .57 & .43 & .67 \\
\hline 2. & Mengumpulkan dan menglasifikasi data & .00 & 1.43 & .00 & .00 \\
\hline 3. & Mengintepretasi data dan membuat grafik & .94 & 1.00 & .86 & 1.00 \\
\hline 4. & Memanipulasi dan menganalisis data & .19 & .14 & .07 & .11 \\
\hline 5. & Memahami hubungan spasial & .00 & .00 & .00 & .00 \\
\hline 6. & Mengukur dan mengamati & .00 & .00 & .00 & .00 \\
\hline 7. & Melakukan eksperimen & .75 & .86 & .93 & .89 \\
\hline 8. & Memprediksi jawaban dan hipotesis & .38 & .71 & .00 & 2.00 \\
\hline 9. & Menyimpulkan data & .31 & .14 & .57 & .00 \\
\hline 10. & Mengolah angka dan memecahkan masalah & .19 & 1.71 & .00 & .33 \\
\hline Rata-rata & .35 & .66 & .29 & .50 \\
\hline
\end{tabular}

Sumber : hasil olahan SPSS 16.0

Dari uraian di atasdisimpulkan,mayoritaspeserta didikmemiliki kesulitan belajar IPA (Sains) berkategori tinggi, namunpada kelompok atas dapat dikategorikan cukup mampu. Semua subyek berkesulitan belajar IPA (Sains) dalam hal: (1) memahami hubungan spasial; (2) mengukur dan mengamati; disusul aspek (3) menyimpulkan data.Kesulitan peserta didik pada aspek: menyimpulkan data yang menunjukkan kategori sangat tinggi perlu mendapatkan perhatian ekstra, sebab kesulitan pada aspek ini dapat menyebabkan peserta didik berkesulitan dalam penalaran, memanipulasi atau mengelola,serta mentranformasi informasi (Santrock, 2010) di mana merupakan bagian dasar dari proses berpikir Sains.

Dari Tabel 3 dapat diamati pula bahwa, secara umum peserta didik cenderung belajar IPA (Sains) cukup baik terutama aspek: (1) pemahaman konsep; (3) melakukan eksperimen;(3) memprediksi jawaban dan hipotesis 
berkategori cukup baik. Fakta di atas mengindikasikan, pola pembelajaran dan materi pelajaran IPA (Sains) yang ajarkanguru cenderungmenekankan pada penguasaan kumpulan pengetahuan berupa fakta-fakta, konsep-konsep atau prinsip-prinsip (Santrock, 2010)serta prosedur yang readinessatau siap pakai (diperoleh dari buku ajar atau guru) dari pada membangun kemampuan diri peserta didikdalam berpikir.

Berdasarkan paparan di atas, dalam pembelajaran IPA (Sains) guru hendaknya mengedepankan membangun kemampuan peserta didik dalam: bernalar dan berpikir, mengembangkan rasa ingin tahu serta berorientasi aplikatif bidang IPA (Saintifik), terutama lebih menekankan pada aspek kemampuan sains yaitu: (1) memahami hubungan spasial; (2) mengukur dan mengamati; serta (3) menyimpulkan data. Pendekatan yang dilakukan guru menggunakankonstruktivis, yaitu pembelajaran yang secara aktif mendorong peserta didik untuk menyusun dan membangun (to cunstruct) pengetahuan dan pemahaman (Santrock, 2010) sains dalam dirinya melalui kegiatan menemukan pengetahuan, merenung, dan berpikir kritis (Brooks dan Brooks, 2001, Santrock, 2010) melalui kegiatan penemuan dan investigasi laboratorium atau menyelesaian permasalahan sehari-hari dalam konteks dunia peserta didik.

\section{Analisis Pembanding Kluster Subyek}

Analisis terhadap data pembanding dengan teknik tabulasi silang (crosstab analysis)menggunakan data ketuntasan hasil UTS masing-masing subyek menunjukkan, pada kelas VIII-1 bahwa terdapat 5 peserta didik dari 8 peserta didik yang tuntas UTS masuk ke dalam kelompok bawah pada tes diagnostik kesulitan belajar IPA. Sementara itu, terdapat 4 peserta didik dari 11 peserta didik yang tidak tuntasUTS masuk dalam kelompok atas pada tes diagnostik kesulitan belajar IPA. Fakta yang hampir sama terjadi pada kelas VIII-4, di mana terdapat 5 peserta didik dari 6 peserta didik yang tuntasUTS masuk kelompok bawah pada tes diagnostik. Sementara itu, terdapat 8 peserta didik dari 17 peserta didik yang tidak tuntasUTS masuk kelompok atas pada tes diagnostik kesulitan belajar IPA.Fakta tersebut seharusnya mengikuti fungsi linier, di mana siswa yang tuntas UTS seharusnya masuk ke dalam kelompok atas pada tes diagnostik.

Fakta tersebut mengindikasikan terjadi ketidaksesuaian antara materi pembelajaran IPA (Sains) yang diajarkan guru terhadap materi tes diagnostik yang dikembangkan peneliti.Terdapat dua indikasi penyebab fenomena tersebut. Indikasi pertama, bahwa materi pelajaran IPA (Sains) yang disampaikan oleh guru lebih menekankan sebagai fakta, konsep, prosedur secara teoritis daripada filosofi pembelajaran IPA (Sains) sebagai matapelajaran untuk mencari tahu tentang alam melalui proses penemuan secara sistematis dan ilmiah (saintifik) (Santrock, 2010). Indikasi kedua, IPA (Sains) di sekolah selama ini masih diajarkan sebagai pengetahuan disiplin ilmu yang terpisah (Fisika, Biologi, dan Kimia), bukan sebagai IPA Terpadu

(Science

Integration)(Kemendiknas, 2012) yang lebih berorientasi melatih peserta didik untuk menyelesaiakan masalah.

Tabel 4. Ketuntasan * Cluster Number of Case Crosstabulation

\begin{tabular}{|l|c|c|c|c|c|c|}
\hline & \multicolumn{3}{|c|}{ Kelas VIII-1 } & \multicolumn{3}{c|}{ Kelas VIII-4 } \\
\cline { 2 - 7 } & $\begin{array}{c}\text { kelompok } \\
\text { bawah }\end{array}$ & $\begin{array}{c}\text { kelompok } \\
\text { atas }\end{array}$ & Total & $\begin{array}{c}\text { kelompok } \\
\text { bawah }\end{array}$ & $\begin{array}{c}\text { kelompok } \\
\text { atas }\end{array}$ & Total \\
\hline Ketuntas tuntas Jumlah & 5 & 3 & 8 & 5 & 1 & 6 \\
\hline
\end{tabular}




\begin{tabular}{|c|c|c|c|c|c|c|c|c|}
\hline \multirow[t]{3}{*}{ an } & & $\begin{array}{l}\% \text { within } \\
\text { Cluster } \\
\text { Number of } \\
\text { Case }\end{array}$ & $31.2 \%$ & $42.9 \%$ & $34.8 \%$ & $35.7 \%$ & $11.1 \%$ & $26.1 \%$ \\
\hline & & Jumlah & 11 & 4 & 15 & 9 & 8 & 17 \\
\hline & $\begin{array}{l}\text { tidak } \\
\text { tuntas }\end{array}$ & $\begin{array}{l}\% \text { within } \\
\text { Cluster } \\
\text { Number of } \\
\text { Case }\end{array}$ & $68.8 \%$ & $57.1 \%$ & $65.2 \%$ & $64.3 \%$ & $88.9 \%$ & $73.9 \%$ \\
\hline \multirow[t]{2}{*}{ Total } & & Jumlah & 16 & 7 & 23 & 14 & 9 & 23 \\
\hline & & $\begin{array}{l}\% \text { within } \\
\text { Cluster } \\
\text { Number of } \\
\text { Case }\end{array}$ & $100.0 \%$ & $100.0 \%$ & $\begin{array}{c}100.0 \\
\%\end{array}$ & $100.0 \%$ & $100.0 \%$ & $\begin{array}{c}100.0 \\
\%\end{array}$ \\
\hline
\end{tabular}

Sumber : hasil olahan SPSS 16.0

Berdasarkan paparan di atas, terdapat pendekatan yang harus dilakukan guru, yaitu mengembangkan perangkat pembelajaran IPA yang mengacu pada IPA Terpaduyang berorientasi melatih peserta didik agar mampu menyelesaikan masalah dalam kehidupan seharihari.Oleh karena itu, perlu dikembangkan (IPA) Sains yang terintegrasi antarkurikulum sekolah, misalnya misalnya dengan matapelajaran sosial, budaya, kewarganegaraan, dan lainlain.Melalui pendekatan tersebut diharapkan peserta didik lebih tertarik pada IPA (Sains) yang membahas persoalan sehari-hari yang relevan dengan kehidupan daripada mendiskusikan teoriteori abstrak (Santrock, 2010).

\section{KESIMPULAN DAN SARAN \\ Kesimpulan}

a) Berdasarkan hasil analisis kluster, kesulitan belajar IPA (Sains) peserta didik SMP Negeri 3 Sumenep berkategori tinggi hampir pada semua aspek kompetensi saintifik, terutama pada aspek: (1) memahami hubungan spasial; (2) mengukur dan mengamati; dan (3)menyimpulkan data.

b) Guru terindikasi mengajarkan IPA sebagai kumpulan teori konseptual daripada membangun kemampuan peserta didik dalam bernalar dan berpikir; mengembangkan rasa ingin tahu; serta berorientasi aplikatif bidang IPA (Saintifik) dalam kehidupan sehari-hari.

c) Berdasarkan hasil cross tab antara ketuntasan UTS terhadap hasil tes diagnostik kesulitan belajar IPA (Sains) ditemukan hasil yang unik, yang mengindikasikan bahwa materi pelajaran IPA (Sains) yang disampaikan guru (mengacu pada disiplin ilmu yang terpisah) tidak sesuai dengan materi tes diagnostik yang dikembangkan peneliti (mengacu pada Sains Terpadu yang dikembangkan PISA OECD tahun 2012).

\section{Saran}

a) Guru dalam pembelajarannya hendaknya mengedepankan membangun kemampuan peserta didik dalam bernalar dan berpikir, mengembangkan rasa ingin tahu serta berorientasi aplikatif bidang IPA (Saintifik), terutama pada aspek: (1) memahami hubungan spasial; (2) mengukur dan mengamati; serta menyimpulkan data.

b) Pendekatan pembelajaran yang dilakukan guru hendaknya 
mengacu pada konstruktivis, yang aktif mendorong peserta didik mengonstruk pengetahuan dan pemahamannya melalui kegiatan penemuan dan investigasi laboratorium atau menyelesaian permasalahan sehari-hari dalam konteks dunia peserta didik.

c) Pembelajaran IPA (Sains) guru hendaknya mengacu pada IPA Terpadu (Integrative Science)terintegrasi

antarkurikulum sekolah, yang berorientasi melatih peserta didik agar mampu menyelesaikan masalah dalam kehidupan seharihari.

\section{DAFTAR PUSTAKA}

Peraturan Mendiknas No. 22, 23, 24 Tahun 2006 tentang Standar Isi dan Standar Kompetensi Lulusan Tingkat Sekolah Menengah Pertama dan Madrasah Tsanawiyah. 2006. Jakarta: Departemen Pendidikan Nasional

Dahar, Ratna Wilis. 2011. Teori-teori Belajar dan Pembelajaran. Jakarta: Erlangga

Dirjen Pendidikan Dasar dan Menengah. 2003. Pedoman Pengembangan Tes Diagnostik Sains SMP. Departemen Pendidikan Nasional: Direktorat Pendidikan Lanjutan

Hakim, Thursan. Belajar Secara Efektif. 2000. Jakarta: Puspa Swara

Hanafiah, Nanang dan Cucu Suhana. 2009. Konsep Strategi Pembelajaran. Bandung: Refika Aditama

Hidayati, Fajar. 2010. Kajian Kesulitan Belajar Peserta didik Kelas VII SMP Negeri 16 Yogyakarta Dalam Mempelajari Aljabar. Skripsi Sarjana Universitas Negeri Yogyakarta tidak untuk dipublikasikan
Hudgins, Bryce B., et.al. 1983. Educational Psychology. Illionis: F.E. Peacock Publisher, Inc.

Karim, Saeful dkk. 2008. Belajar IPA Membuka Cakrawala Alam Sekitar. Jakarta: Pusat Perbukuan, Departemen Pendidikan

Santrock, John. 2010. Psikologi Pendidikan, edisi dua. Jakarta: Kencana Prenada media Goup

Suarto.2013. Pengembangan Tes Disgnostik dalam Pembelajaran. Yogjakarta: Pustaka Pelajar

Suryanih. 2011. Diagnosis Kesulitan Belajar Matematika Peserta didik dan Solusinya Dengan Pembelajaran Remidial. Skripsi Program Gelar Sarjana UIN Syarif Hidayatullah Jakarta tidak untuk dipublikasikan

Syah, Muhibbin. 2012. Psikologi Belajar. Jakarta: PT. Raja Grafindo Persada Trianto. 2008. Mendesain Pembelajaran Kontekstual (CTL) di Kelas. Jakarta: Cerdas Pustaka Publisher

Widdiharto, Rachmadi. 2008. Diagnosis Kesulitan Belajar Matematika SMP Dan Alternatif Proses Remidinya. Yogyakarta: Pusat Pengembangan dan Pemberdayaan Pendidik dan Tenaga Kependidikan Matematika

Winkel. W. S. 2004. Psikologi Pengajaran. Yogyakarta: Media Abadi. 